\title{
Applicability of a Solar Adsorption Cooling Machine in Semiarid Regions: Proposal of Supplementary Cooler Using Earth-Water Heat Exchanger
}

\author{
Amar Rouag ${ }^{1 *}$, Adel Benchabane ${ }^{1}$, Adnane Labed ${ }^{2}$, Khaled Belhadj ${ }^{1}$ and Nora Boultif ${ }^{1}$ \\ ${ }^{1}$ Laboratoire de Génie Energétique et Matériaux, LGEM, Université de Biskra, B.P.145 R.P. \\ 07000 Biskra, Algeria \\ ${ }^{2}$ Laboratoire de Génie Mécanique, Université de Biskra, B.P. 145 R.P. 07000 Biskra, Algeria
}

Email: rouagamar@yahoo.com

\begin{abstract}
This paper interests to the applicability of the solar adsorption air refreshment systems in the semiarid region of Biskra (Algeria) and the water cooling system was investigated. We proposed the replacement of the dry cooling tower (DCT) used in the main system with a supplementary water cooling system based on shallow geothermal energy by using earth-water heat exchanger (EWHE). The supplementary EWHE operates just when the ambient temperature exceeds the operating limits of the DCT. Thus, we have modeled and sized the EWHE by FORTRAN programming code. After the code validation, we have designed the appropriate EWHE to the region keeping the same pressure drop and respecting all the functioning conditions of an experimental SACM found in the literature. Results are very significant and showed that the geothermal solution can effectively replace the DCT and presents an important reduced cost compared with other solutions.
\end{abstract}

Keywords: Solar adsorption chiller, Earth-water heat exchanger, Geothermal energy, Sizing, Dry cooling tower.

\section{INTRODUCTION}

Up to now air conditioning and domestic cooling systems in Algeria mainly operate in the traditional way, which needs an important expenditure of electrical energy. These technologies use CFCs for their operation, most of which deplete the ozone layer. The alternative systems must use safe refrigerants for the environment and have a high performance to reduce $\mathrm{CO}_{2}$ emissions and therefore reduce the greenhouse effect.

The environmental problems have given a renewed interest to another system (field) called sorption chillers (adsorption and absorption). These alternatives machines become increasingly attractive because the fluids used, in these systems, are benign to the environment whatsoever ammonia, water or alcohols ... etc. This technology is particularly attractive for the countries which have a very important solar potential.

This work focus on the possibility of installing a solar adsorption machine in the region of Biskra in the Southeast of Algeria [1]. This type of installations includes a set of thermal systems such as: cooling machine (Chiller), the solar heating system and cooling system (cooling tower, aircooler...).

The biggest problem objected to the system operating in the semiarid and Saharan regions is how to provide cold water to cool the adsorbers, unlike hot water which we get it easily from solar water heaters. A lot of geometries are suggested to the coolers design in the literature [2-8].

Citherlet et al. [2] analyzed the performances of the solar adsorption chiller in Switzerland, they used a solar adsorption cooling machine (SORTECH ACS08) with a nominal cooling capacity of $8 \mathrm{~kW}$. This chiller uses the silica gel/water as working pair, with a finned tubes heat exchanger (dry cooling tower) DCT as a recooler with $287 \mathrm{~m}^{2}$ of heat transfer area to cool the cooling water. Results showed that in the case when the ambient air temperature exceeds $34^{\circ} \mathrm{C}$, the DCT doesn't work well.

In the semiarid and Saharan zones, like Biskra (south-east of Algeria), the average ambient temperature can exceed $34^{\circ} \mathrm{C}$ in all the summer and can reach $35^{\circ} \mathrm{C}$ in July and August as shown in Fig. 1 [9]. Thus, the DCT efficiency decreases, which make it unable to cool the cooling water to the desired temperature. A hybrid cooling tower can improve the operating limits of the system. However, this makes it more complex, without forgetting the scarcity of water in these regions.

Due to the fact that ground temperature is always lower than air temperature in summer, the solar assisted groundsource cooling system increases system efficiency $[10,11]$ and makes it a very attractive technology especially in the Saharan regions. 


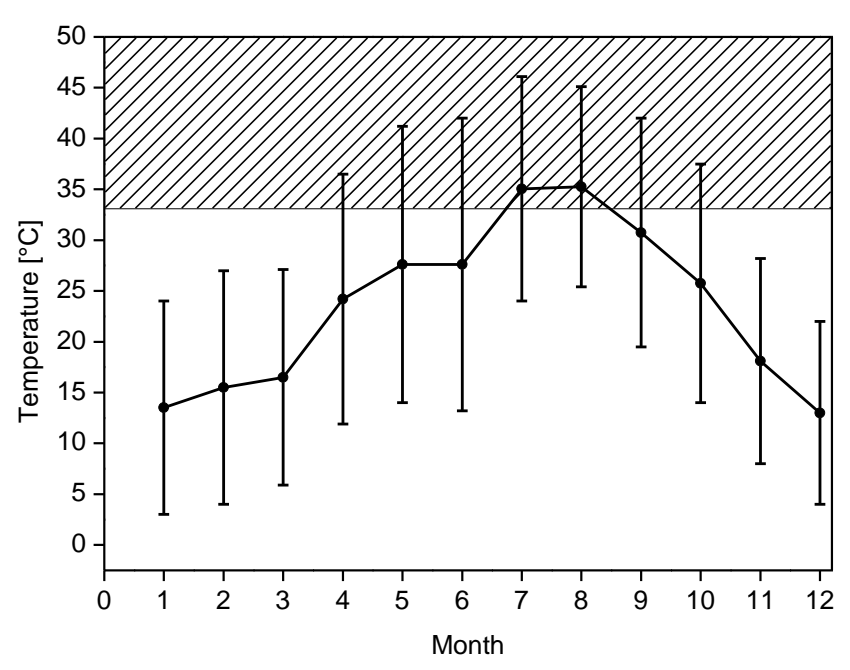

Figure 1. Evolution of the average monthly ambient temperature in the region of Biskra (2014) [9]

In an attempt to solve this problem; the present paper suggests the exploitation of the shallow geothermal energy by using an earth-water heat exchanger EWHE as a cooler to replace the DCT when the ambient temperature exceeds its operating limits. For that we have designed the appropriate EWHE to the region of Biskra to replace a DCT found in the literature.

\section{SOLAR ADSORPTION COOLING MACHINE, SACM, DESCRIPTION}

\subsection{SACM with DCT}

An adsorption cooling machine (chiller) consists of the condenser, evaporator and an adsorber (or two adsorbers) containing the adsorbent, which replace the compressor in the conventional vapor compression refrigeration system. The machine can be characterized by three temperatures:

i) High temperature coming from the solar water heater corresponding to the driving heat provided to the system,

ii) low temperature corresponding to that of the cold production,

iii) middle temperature at which the quantity of the withdraw heat from the chilled water coming from the cooling tower and the driving heat must be discharged.

In the Saharan and semiarid regions characterized by high ambient temperatures, especially in summer, it is difficult to provide the cooling water to cool the system.

Citherlet et al [2] and Lu et al [5] used a dry cooling tower DCT which uses the ambient air as a cooling fluid (Fig 2.), Table. 1 shows the main characteristics of the cooling tower used by Citherlet et al.

Table 1. Characteristics of the cooling tower used by [2]

\begin{tabular}{ll}
\hline Fluid & Ethylene glycol 34 Vol. \% \\
\hline Tube material & Copper \\
Pipes Internal diameter $(\mathrm{m})$ & 0.016 \\
Tubes thickness $(\mathrm{m})$ & 0.002 \\
Heat transfer area $\left(\mathrm{m}^{2}\right)$ & 270.6 \\
Fan capacity $(\mathrm{kW})$ & 0.4 \\
Number of fans & 2 \\
\hline
\end{tabular}

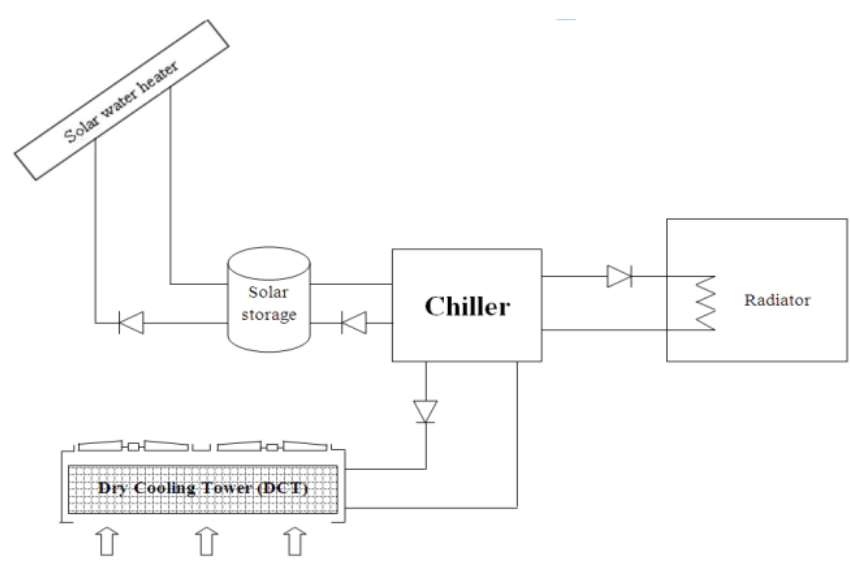

Figure 2. Schematic presentation of solar adsorption chiller operates with dry air cooling tower DCT

However, the operating limits of this solution don't exceed $33-35^{\circ} \mathrm{C}$ [2], which forces the use of sprays to improve the yield. These sprays consume a lot of water, which is rare in these regions, in addition to the need to provide pumps to ensure the flow of spray water.

\subsection{SACM with EWHE}

In this paper we propose the use of shallow geothermal energy to cool the cooling water by using an earth-water heat exchanger (EWHE) buried at a depth of $3 \mathrm{~m}$ (This depth has been previously determined by a study based on local data of the region) $[12,13]$ under the ground surface Fig. 3.

The EWHE replaces the DCT in the case when the ambient air temperature exceeds operating limits of the DCT (see Fig. 2). Table 2 shows the main characteristics of this heat exchanger.

Table 2. Characteristics of the proposed EWHE

\begin{tabular}{ll}
\hline Fluid & Ethylene glycol 34 Vol. \% \\
\hline Pipe nature & HDPE \\
Pipe thermal conductivity & $0.46 \mathrm{~W} /(\mathrm{mK})[14]$ \\
Pipe buried depth & $3 \mathrm{~m}$ \\
\hline
\end{tabular}

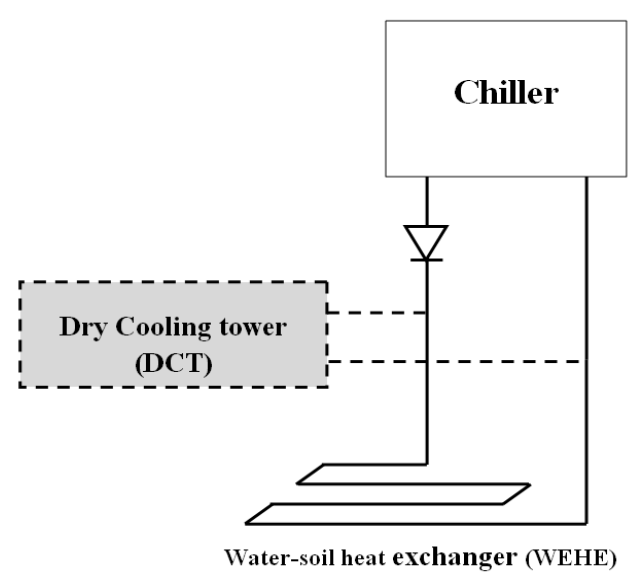

Figure 3. Scheme of solar adsorption chiller operates with water-soil heat exchanger EWHE as supplementary cooler 


\section{SIZING METHOD AND VALIDATION MODEL}

\subsection{Sizing calculation method}

The following assumptions were made in modeling the system: (i) The maximum duration of continuous operation of the EWHE doesn't exceed few hours just during the peak temperatures (ii) analysis is based on steady state conditions, (iii) the soil around the heat exchanger is homogenous, (iv) soil conductivity is constant, (v) water flow is uniform along the length of the buried pipes (vi) Thermo-physical properties of water are calculated using correlation from literature, and finally (vi) we assumed that the soil properties are isotropic and there is perfect contact between the soil and the pipe.

The calculation model is based on the resolution of the heat equation (Fig. 4):

$m C p(T(x)-T(x+d x))=\frac{(T(x)-T s)}{R_{t h}} d x$

where $R_{\text {th }}$ is the overall thermal resistance between pipe water and surrounding soil of the water soil heat exchanger can be expressed by the relation(2) [15]:

$R_{t h}=R_{w}+R_{t}+R_{s}$

The thermal resistance Rw due to convective heat transfer between water in the pipe and the inner surface of the pipe calculated as:

$R_{w}=\frac{1}{h_{i} P_{i}}$

where

$h_{i}=N u \lambda_{w} / d i$

The Nusselt number for water flow inside a pipe given by Eq. (5) [16] is a function of Reynolds number $R e$, and Prandlt number for, $2300<\operatorname{Re}<10^{5}$ and $1.5<\operatorname{Pr}<500$

$N u=0.012\left(\operatorname{Re}^{0.87}-280\right) \operatorname{Pr}^{0.4}\left[1+\left(\frac{d i}{L}\right)^{0.66}\right]$

The thermal resistance of the tube Rt:

$R_{t}=\frac{\ln \left(r_{e} / r_{i}\right)}{2 \pi \lambda_{t} L}$
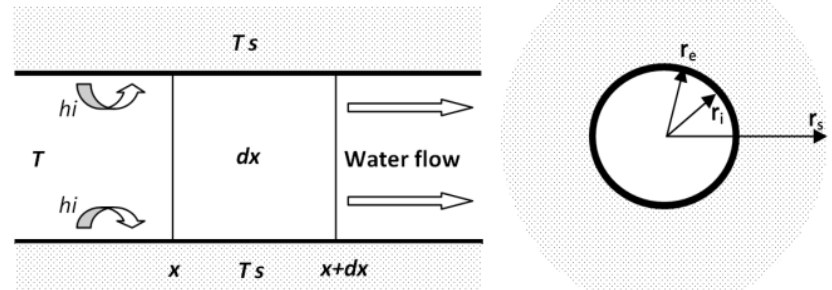

Figure 4. Thermal balance of a pipe elementary segment
The thermal resistance Rs of the soil annulus is given by the Eq. (7)

$R_{s}=\frac{\ln \left(r_{s} / r_{e}\right)}{2 \pi \lambda_{s} L}$

Several works in the literature have considered the appropriate thickness of the soil annulus. As a conclusion to all of these researches, the soil thickness is varying with the duration of operation of the heat exchanger. In this paper, the duration of operation of the WEHE doesn't exceed few hours. For that, the thickness of the soil annulus was taken as being equal to the radius of the pipe $\left(r_{s}=2 r_{i}\right)$. [17-19]

After dividing the Eq.(1) on $\mathrm{dx}$ this equation can be written as following :

$-m C p \frac{d T}{d x}=\frac{(T(x)-T s)}{R_{t h}}$

Then

$T(x)=A \exp \left(\frac{-x}{m C p R_{t h}}\right)+\mathrm{B}$

We can determine the constants $\mathrm{A}, \mathrm{B}$ if we take into account boundary conditions:

- For $=>\infty, T(x)=T_{s}===>B=T_{s}$;

- For $x=0, T(x)=T_{0} \quad===>A=T_{0}-T_{s}$

$T(x)=\left(T_{0}-T_{s}\right) \exp \left(\frac{-x}{m C p R_{t h}}\right)+T_{s}$

Also we can write the eq. (10) as:

$T(x)=\left(T_{0}-T_{s}\right) \exp \left(\frac{-x}{\rho C p S v R_{t h}}\right)+T_{s}$

Pressure drop in the heat exchanger is equal to the sum of the linear, singular and pressure losses between the inlet and outlet of the exchanger [20].

$\Delta P_{t}=\Delta P_{\text {lin }}+\Delta P_{\text {sin }}+\Delta P_{i o}$

Where the linear pressure losses are calculated as [21]:

$\Delta P_{\text {lin }}=\Lambda \rho_{w} L \frac{v_{w}^{2}}{2 \mathrm{~d}}$

The calculation of the loss ratio of load $\Lambda$ depends on the nature of the flow, laminar or turbulent [20].

For $2100<\operatorname{Re}<10^{5}$, the BLASUIS formula is used

$\Lambda=0.3164 \mathrm{Re}^{-0.25}$

The singular pressure loss is defined by 
$\Delta P_{\sin }=\xi \rho_{w} \frac{v_{w}^{2}}{2}$

Pressure losses due to the inlet and outlet of the heat exchanger are calculated as following [20]:

$\Delta P_{i o}=\frac{3}{4} \rho_{w} v_{w}^{2}$

\subsection{Model validation}

In this paper we have validated the calculation code with the experimental data obtained by Moummi et al. [12], in the University of Biskra. The authors used an earth-air heat exchanger, using the same (geometric and climatic) data. The specific parameters and characteristics of the heat exchanger tested by Moummi et al. [12] are given in Table 2.

In order to validate the calculation method, we have provided a simple comparison between the results from this study and the literature in Fig. 5. The comparison results show that a good agreement had been found between the air temperatures calculated in this study with the ones reported in the literature. The code reflects the real phenomenon with a maximum field error of $\left(1^{\circ} \mathrm{C}\right)$, which can be relied upon to design the water-earth heat exchanger (WEHE).

\section{APPLICABILITY OF THE EWHE IN BISKRA}

To be able to compensate the cooling tower by the earthwater heat exchanger (EWHE); the pressure drop in both systems must be the same, for that, we sized the EWHE with a maximum total pressure drop equal to 0.3 bar as the Citherlet's et al. [2] machine. The sizing was made by using the same input/output parameters (see Table. 3).

It must be mentioned that in EWHE we can't use copper as a tube material due to the corrosion, for that, we used the High Density Polyethylene (HDPE) pipes with a thermal conductivity of $\lambda=0.46 \mathrm{~W} /(\mathrm{mK})$ where the soil temperature $\mathrm{Ts}=26^{\circ} \mathrm{C}$ in August [13].

Figure 6 shows the influence of the pipe diameter on the total pressure drop for different pipes diameters. Results indicate that the minimum diameter which we can be used is $0.033 \mathrm{~m}$ whatever the pipes length.

In addition, EWHE must be able to decrease the water temperature to the desired value $\left(34^{\circ} \mathrm{C}\right)$, Fig. 7 illustrates the influence of the pipe diameter on the water outlet temperature for different lengths.

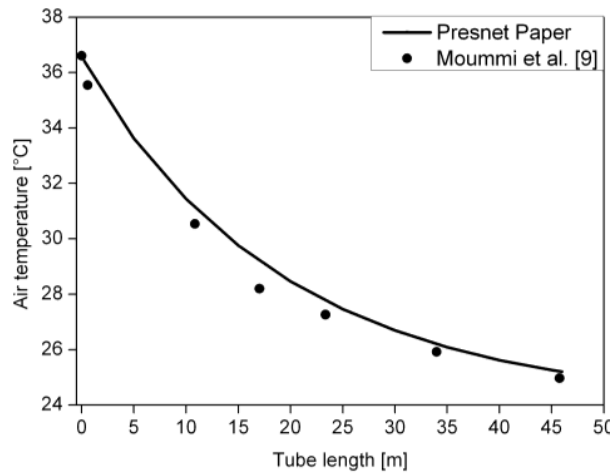

Figure 5. Comparison with N. Moummi et al. [12]
Table 2. Moummi et al. [12] heat exchanger parameters

\begin{tabular}{ll}
\hline Pipe materiel & PVC \\
Length of pipe $(\mathrm{m})$ & 60 \\
Piping depth $(\mathrm{m})$ & 3 \\
Internal diameter $(\mathrm{m})$ & 0.11 \\
Pipe thikness $(\mathrm{m})$ & 0.003 \\
Inlet temperature $\left({ }^{\circ} \mathrm{C}\right)$ & 36.572 \\
Outlet temperature $\left({ }^{\circ} \mathrm{C}\right)$ & 24 \\
volumetric flow rate $\left(\mathrm{m}^{3} / \mathrm{h}\right)$ & 155.43 \\
\hline
\end{tabular}

Table 3. Input/output Parameters of Citherlet et al. [2] DCT

\begin{tabular}{ll}
\hline Fluid & Ethylene glycol 34 Vol. \% \\
Inlet temperature $\left({ }^{\circ} \mathrm{C}\right)$ & 41 \\
Outlet temperature $\left({ }^{\circ} \mathrm{C}\right)$ & 34 \\
Mass flow rate $(\mathrm{Kg} / \mathrm{s})$ & 0.9308 \\
\hline
\end{tabular}

From the graphic results of Fig. 7, it can be concluded that when the outlet water temperature reaches the value of $34{ }^{\circ} \mathrm{C}$, the minimum pipes length possible is $100 \mathrm{~m}$.

According to the results obtained from Figs 6 and 7, we can draw an applicability zone in the Fig. 7 which defines the geometrical characteristics (length and diameter) of the optimal (appropriate) EWHE in Biskra respecting all the condition of the experimental device of [2].

Table 4. summarizes the main characteristics of the sized EWHE and the DCT of Citherlet et al. [2]. We can conclude that the EWHE can be the best alternative during the peak ambient temperatures in the region of Biskra and at much lower cost, especially that the DCT of the solar adsorption chiller doesn't work at ambient temperatures higher than $34{ }^{\circ} \mathrm{C}$ [2] due of its dependence on the ambient air for the cooling.

Table 4. Characteristics of DCT and the studied EWHE

\begin{tabular}{lll}
\hline & DCT [2] & EWHE \\
\hline Heat transfer area $\left[\mathrm{m}^{2}\right]$ & 270.6 & 10.37 \\
Pipes length [m] & 600 & 100 \\
Tube diameter[m] & 0.016 & 0.033 \\
Pressure drop [bar] & 0.3 & 0.3 \\
\hline
\end{tabular}

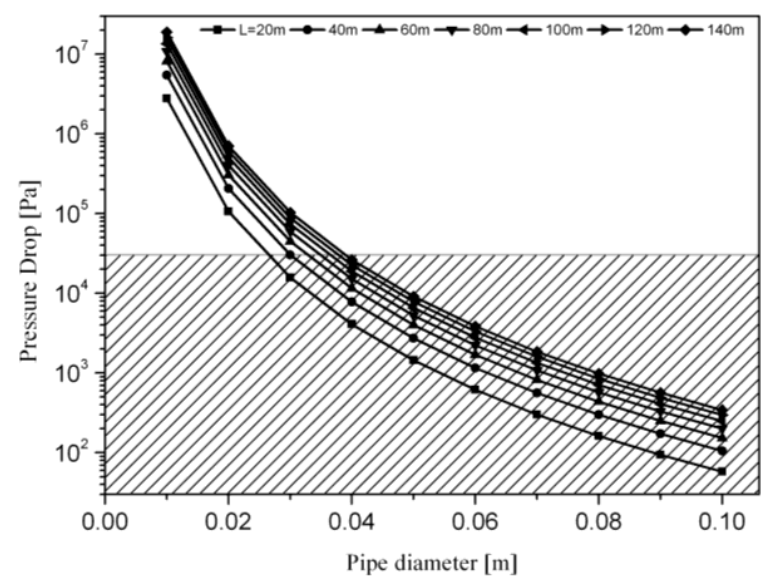

Figure 6. Influence of the pipe diameter on the total pressure drop for different pipe length 


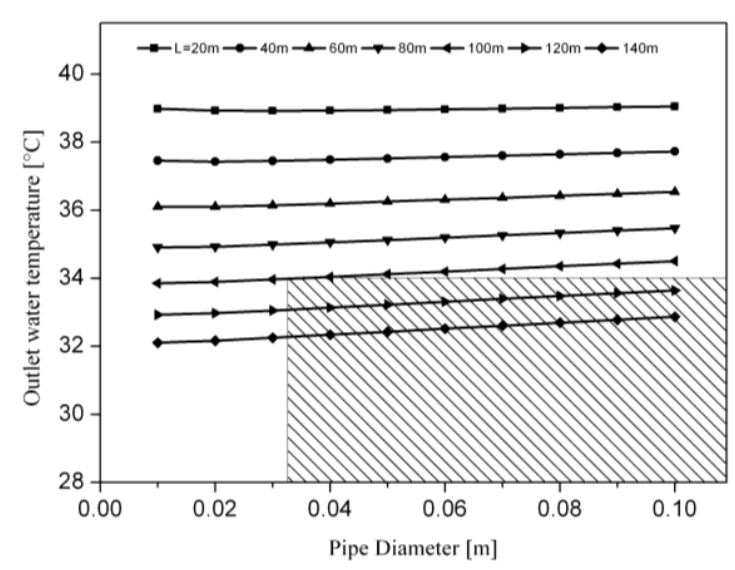

Figure 7. Influence of the pipe diameter on the water outlet temperature for different pipes length

\section{CONCLUSION}

In this work, we are interested in the applicability of the solar adsorption air refreshment system in the region of Biskra and the water cooling system was investigated. Previous work in the literature used a finned tubes heat exchanger (dry cooling tower DCT) in the SACM and showed that when the ambient air temperature exceeds $34^{\circ} \mathrm{C}$, the heat transfer area needed of the heat exchangers increases enormously.

In this paper we have proposed a supplementary water cooling system to the chiller based on shallow geothermal energy by using an earth-water heat exchanger (EWHE). The proposed EWHE operates just during the peak ambient temperatures to avoid the dysfunctioning of the DCT. Through the modeling work of the EWHE, we have designed WEHE in Biskra. Results are very encouraging and show that the geothermal solution is effective; with a very low cost.

Continuous use of the EWHE causes the saturation of the soil because of the low thermal diffusivity of this last, where the soil temperature in the immediate vicinity of the heat exchanger increases which causes the decrease of its efficiency. For that, another study to know the influence of the EWHE on the soil and the influence of soil on the EWHE as a function of time is required to ensure continuous water cooling. This study will allow us to define how many exchanger must be used, distance between the tubes and also between the geothermal heat exchangers in the case of the abolition of the use of the DCT completely.

\section{ACKNOWLEDGMENT}

This study was supported by Algerian Ministry of Higher Education and Scientific Research as a part of project CNEPRU (J0301420110028)

\section{REFERENCES}

[1] A. Labed, N. Moummi, A. Benchabane and M. Zellouf, "Experimental analysis of heat transfer in the flow channel duct of solar air heaters (SAHs)," International Journal Of Heat And Technology, vol.
33 no. 3, pp. 97-102, 2015. DOI: 10.18280/ijht.330314.

[2] S. Citherlet, C. Hildbrand, J. Bony, A. Kleijer, M. Bunea and S. Eicher, "Analyse des performances de la climatisation solaire par adsorption et potentiel pour la Suisse," Rapport final, Projet SOLCOOL HEIG-VD, Office fédérale de l'énergie OFEN, Rept. 152645, 25 Janvier 2011

[3] Y. L. Liu, R. Z. Wang and Z. Z. Xia, "Experimental study on a continuous adsorption water chiller with novel design," International Journal of Refrigeration, vol. 28 no. 2 , pp. 218-230, 2005. DOI: 10.1016/j.ijrefrig.2004.09.004.

[4] Z. Lu, R. Wang, Z. Xia, Q. Wu, Y. Sun and Z. Chen, "An analysis of the performance of a novel solar silica gele-water adsorption air conditioning," Applied Thermal Engineering, vol. 31 no. 17, pp. 3636-3642, 2011. DOI: 10.1016/j.applthermaleng.2010.11.024.

[5] Z. S. Lu, R. Z. Wang, Z. Z. Xia, X. R. Lu, C. B. Yang, Y. C. Ma and G. B. Ma, "Study of a novel solar adsorption cooling system and a solar absorption cooling system with new CPC collectors," Renewable Energy, vol. 50 pp. 299-306, 2013. DOI: 10.1016/j.renene.2012.07.001.

[6] U. Jakob and W. Mittelbach, "Development and investigation of a compact silica gel/water adsorption chiller integrated in solar cooling systems," Presented at VII Minsk International Seminar: Heat Pipes, Heat Pumps, Refrigerators, Power Sources, Minks, Belarus, pp. 8-11, 2008.

[7] A. Rouag, A. Benchabane, A. Labed and N. Boultif, "Use of shallow geothermal energy to improve the efficiency of air heat exchangers: Proposal of a Geothermal Air-Cooler (GAC)," DZ Patent App. 140719, 04-12-2014, Algeria, 2014.

[8] H. Ounis, A. Benchabane and A. Rouag, "Accessory of humidified grid to improve the efficiency of air heat exchangers: Proposal of a mechanism for the aircoolers and condensers," DZ Patent App. 160057, 01/02/2016, Algeria, 2016.

[9] INFO-CLIMAT, Climatologie de l'année 2014 à Biskra, avilable from: http://www.infoclimat.fr/climatologie/annee/2014/bisk ra/valeurs/60525.html, [acceded 25/05/2014].

[10] A. Macía, L. A. Bujedo, T. Magraner and C. S. R. Chamorro, "Influence parameters on the performance of an experimental solar-assisted ground-coupled absorption heat pump in cooling operation," Energy and Buildings, vol. 66 pp. 282-288, 2013. DOI: 10.1016/j.enbuild.2013.07.012.

[11] W. Yang, L. Sun and Y. Chen, "Experimental investigations of the performance of a solar-ground source heat pump system operated in heating modes," Energy and Buildings, vol. 89 pp. 97-111, 2015. DOI: 10.1016/j.enbuild.2014.12.027.

[12] N. Moummi, H. Benfatah, N. Hatraf, A. Moummi and S. Youcef-Ali, "Le rafraîchissement par la géothermie: étude théorique et expérimentale dans le site de Biskra," Revue des Energies Renouvelables, vol. 13 no. 3, pp. 399 - 406, 2010

[13] Y. Belloufi, A. Brima, R. Atmani, N. Moummi and F. Aissaoui, "Theoretical and experimental study of air refresh by a geothermal heat exchanger air/ground," LARHYSS Journal, vol. 25 pp. 121-137, 2016. DOI: 
[14] D. Kumlutas, I. H. Tavman and M. T. çoban, "Thermal conductivity of particle filled polyethylene composite materials," Composites Science and Technology, vol. 63 no. 1, pp. 113-117, 2003. DOI: 10.1016/S0266-3538(02)00194-X.

[15] O. Ozgener, L. Ozgener and D. Y. Goswami, "Experimental prediction of total thermal resistance of a closed loop EAHE for greenhouse cooling system," International Communications in Heat and Mass Transfer, vol. 38 no. 6, pp. 711-716, 2011. DOI: 10.1016/j.icheatmasstransfer.2011.03.009.

[16] H. Fallahsohi, "Modèlisation dynamique des échangeurs diphasiques, appliquée aux groupes frigorifiques contrôlés par une commande avancée," Doctorate thesis, Laboratoire d'Energétique de l'ECAM de LYON, INSA de Lyon, 161, 2011.

[17] B. Zoellick, "Predicted and observed performance of a buried earth-air heat exchanger cooling system," Presented at Proc. Annu. Meet.-Am. Sect. Int. Sol. Energy Soc, United States, pp. p. 822-6., 1981.

[18] N. Scott, "Analysis and performance of an earth-air heat exchanger," Presented at the 1965 Winter meeting, Chicago, Illinois, pp. 1965.

[19] D. Elmer and G. Schiller, "A preliminary examination of the dehumidification potential of earth to air heat exchangers," Presented at Proceedings of the International Passive Cooling Conference, Miami, Florida, pp. p.161-165., 1981.

[20] I. E. Idelchik, "Memento des pertes de chargecoefficients de pertes de charge singulières et de pertes de charge par frottement," Editions Eyrolles; SaintGermain, Paris: Eyrolles, 1969.

[21] F. Zeng, C. Long and J. Guo, "A novel unsteady model of predicting the productivity of muti-fractured horizontal wells," International Journal of Heat And Technology, vol. 33 no. 4, pp. 117-124, 2015. DOI: 10.18280/ijht.330415.

\section{NOMENCLATURE}

$C p \quad$ Specific heat, $W /(\mathrm{kg} \mathrm{K})$

$d \quad$ Diameter, $m$

v velocity, $\mathrm{m} / \mathrm{s}$

$L \quad$ Tube length/ latent heat, $m$ m mass flow rate, $\mathrm{Kg} / \mathrm{s}$

$h \quad$ Convective heat transfer Coefficient, $W /\left(m^{2} K\right)$

$S \quad$ Surface, $\mathrm{m}^{2}$

$T \quad$ Temperature, ${ }^{\circ} \mathrm{C}$

$R \quad$ Resistance, $\mathrm{m}^{2} \mathrm{~K} / \mathrm{W}$

$r \quad$ Radius, $m$

$P_{i} \quad$ Perimeter, $m$

$\mathrm{P} \quad$ Pressure, $\mathrm{Pa}$

$\mathrm{Nu} \quad$ Nusselt number, -

Re Renolds number, -

$\operatorname{Pr} \quad$ Prandlt number, -

\section{Greeks symbols}

$\lambda \quad$ Thermal conductivity $\mathrm{W} /(\mathrm{mK})$

$\rho \quad$ Density, $\mathrm{kg} / \mathrm{m}^{3}$

$\xi \quad$ Singular loss ratio of load, -

$\Lambda \quad$ Linear loss ratio of load, -

\section{Subscripts}

$\begin{array}{ll}o & \text { Outlet } \\ t h & \text { Thermal } \\ e & \text { External } \\ i & \text { Internal } \\ t & \text { Tube } \\ l i n & \text { Linear } \\ \text { sin } & \text { Singular } \\ \text { io } & \text { Inlet and outlet of the heat exchanger } \\ m & \text { Mean } \\ w & \text { Water } \\ s & \text { Soil } \\ t & \text { Total } \\ \Delta & \text { Difference } \\ \text { in } & \text { inlet }\end{array}$

\section{Abbreviations}

DCT Dry Cooling Tower

EWHE Earth-water heat exchanger

SACM Solar Adsorption Cooling Machine 